\title{
ROLA BISKUPÓW RZYMU W SPORACH DOKTRYNALNYCH STAROŻYTNEGO KOŚCIOLA
}

Stolica Piotrowa była zawsze postrzegana jako ostoja prawowiernego nauczania i troski o zachowanie ortodoksji. Wszak Piotr i wszyscy jego następcy cieszą się obietnicą Zbawiciela: „Ty jesteś Piotr [czyli Skała], i na tej Skale zbuduję Kościół mój, a bramy piekielne go nie przemogą" (Mt 16, 18). Nie znaczy to jednak, jakoby powszechnie we wszystkich wspólnotach w jednakowy sposób uznawano prymat biskupa Rzymu. Można by przeprowadzić tu refleksję nad różnicami w rozumieniu znaczenia i miejsca biskupa Rzymu w Kościele powszechnym przede wszystkim przez patriarchaty wschodnie. Uznawały one jego pierwszeństwo honorowe, a autorytet następcy Piotra widziały w porządku moralnym ${ }^{1}$. W tym kontekście dla Kościoła starożytnego ważny okazał się edykt De fide catholica ogłoszony przez cesarza Teodozjusza w Tessalonice dniu 27 lutego $380 \mathrm{r}$. W dokumencie tym cesarz jednoznacznie stwierdził:

„Pragniemy, aby wszystkie ludy, którym władamy z łagodnością i umiarkowaniem, trwały w wyznawaniu takiej religii, o której żywa do dziś tradycja zaszczepiona przez boskiego Piotra Apostoła głosi, że to właśnie on przekazał ją Rzymianom, i o której wiadomo, że postępuje według niej biskup Damazy i Piotr, biskup Aleksandrii, mąż apostolskiej świętości, mianowicie abyśmy zgodnie z nauczaniem apostolskim i nauką Ewangelii wierzyli w jedno Bóstwo Ojca i Syna i Ducha Świętego, o równym majestacie i w Świętej Trójcy”2.

Wskazanie na biskupa Rzymu jako gwaranta prawowierności było tu oczywiste. Cesarz wskazał wprost na biskupa Damazego, reprezentującego Stolicę Apostolską, jako strażnika ortodoksji. Nieformalne, ale ważne w biegu historii Kościoła, uznanie znaczenia biskupa Rzymu w trosce o zachowanie

${ }^{*}$ Ks. dr hab. Paweł Wygralak, prof. UAM - profesor nadzwyczajny w Zakładzie Teologii Patrystycznej i Historii Kościoła na Wydziale Teologicznym Uniwersytetu im. Adama Mickiewicza w Poznaniu; e-mail: pawelwyg@amu.edu.pl.

${ }^{1}$ Por. Świat Bizancjum, t. 1: Cesarstwo wschodniorzymskie 330-641, red. C. Morrisson, thum. A. Graboń, Kraków 2007, 146.

${ }^{2}$ CT XVI 1, 2 (De fide catholica), ŹMT 71 [tekst łacińsko-polski, oprac. M. Ożóg-M. Wójcik, wstęp M. Stachura, tłum. A. Caba], Kraków $2014=$ SCL 7, 2-2*. Por. W. Ceran, Teodozjusz Wielki, Kraków 2003, 53-54. 
prawowierności przyszło również z najmniej oczekiwanej strony, a mianowicie od niektórych twórców błędnych doktryn. Zwracali się oni bowiem do niego z prośbą o potwierdzenie prawdziwości swego nauczania. Widzieli zatem w następcy św. Piotra autorytet, z którym się liczyli i u którego szukali poparcia.

W niniejszym artykule pragniemy omówić działalność wybranych biskupów Rzymu na rzecz zachowania prawowiernej doktryny Kościoła w związku z wystapieniami Nestoriusza, Eutychesa i Sergiusza, którzy zwrócili się do współczesnych sobie papieży z prośbą o poparcie w sprawie głoszonej przez siebie nauki. Podstawę niniejszego opracowania stanowi przede wszystkim zachowana korespondencja pomiędzy herezjarchami a biskupami Rzymu, biskupami Rzymu a cesarzami oraz orzeczenia soborów i synodów.

1. Celestyn i sprawa Nestoriusza. Nestoriusz zasiadał na stolicy biskupiej w Konstantynopolu w latach 428-431. Jego chrystologia, której efektem było zakwestionowanie tytułu Theotokos przyznawanego Najświętszej Maryi Pannie wzbudziła spore poruszenie wśród wiernych stolicy Imperium, a przede wszystkim wśród miejscowego duchowieństwa. Przeciwko nauczaniu Nestoriusza wystąpił również w homilii wielkanocnej w 429 r. patriarcha Aleksandrii Cyryl, który o sprawie dowiedział z pewnością od rezydującego w Konstantynopolu apokryzjariusza. W odpowiedzi Nestoriusz wyjaśniał swoje stanowisko w kolejnych listach adresowanych do Cyryla ${ }^{3}$. W międzyczasie jednak, widząc nasilające się wokół niego negatywne nastawienie duchowieństwa i wiernych, zwrócił się także do ówczesnego biskupa Rzymu Celestyna († 432). W napisanym do niego niezbyt długim liście starał się wyjaśnić swoje poglądy ${ }^{4}$. Do listu załączył teksty swoich kazań, w których zawarł głoszoną przez siebie naukę. Tekst czterech kazań patriarchy wysłał do Rzymu również człowiek świecki, Euzebiusz, przeciwnik Nestoriusza, późniejszy biskup Dorylei ${ }^{5}$. Patriarcha nie przewidział jednak, że w Rzymie nie lada problemem będzie lektura tekstów zredagowanych w języku greckim. Wspomni o tym sam papież w odpowiedzi na listy Nestoriusza. W tym punkcie bardziej przewidującym okazał się Cyryl Aleksandryjski, który wysłał do Rzymu dokumenty sprawy przetłumaczone już na język łaciński ${ }^{6}$. Celestyn podejmując się rozstrzygnięcia sporu, przekazał pisma Nestoriusza do osądu Jana Kasjana. Na podstawie jego opinii, jak również dokumentów dostarczonych przez Cyryla, w których przedstawił on swoje stanowisko na temat nauczania Nestoriusza, Celestyn potępił poglądy Nestoriusza na synodzie zwołanym w Rzymie

${ }^{3}$ Por. B. Sesboüé, Chrystologia i soteriologia, Efez i Chalcedon (IV-V wiek), w: Historia dogmatów, t. 1: Bóg zbawienia, red B. Sesboüé, thum. P. Rak, Kraków 1999, 330-339.

${ }^{4}$ Por. Nestorius, Epistula 6 [ad Coelestinum Papam Urbis Romae], PL 50, 438-441. Zob. M. Karas, Życie Nestoriusza, patriarchy Konstantynopola (V w.), „Nowy Filomata” 4 (2001) 266. Pomijamy zagadnienia dotyczące listu Nestoriusza do Celestyna w sprawie pelagianizmu.

${ }^{5}$ Por. SWP 290.

${ }^{6}$ Por. M. Starowieyski, Sobory niepodzielonego Kościoła, Kraków 2016, 76. 
w dniu 11 sierpnia $430 \mathrm{r}$. W skierowanym do Nestoriusza liście wezwał go do odwołania w ciągu dziesięciu dni - przyznajmy jest to czas niedługi - głoszonej nauki ${ }^{7}$. Jednocześnie skierował list do duchowieństwa i wspólnoty wiernych w Konstantynopolu, w którym poinformował o swoim stanowisku wobec nauczania Nestoriusza, a także o misji powierzonej Cyrylowi Aleksandryjskiemu. Warto zwrócić uwagę, że w liście tym zapewniał adresatów, że celem wszystkich podjętych działan jest pomoc Nestoriuszowi, czego wyrazem jest ofiarowany mu okres czasu na rewizję głoszonych tez ${ }^{8}$.

Podsumowując udział Celestyna w zwalczaniu nestorianizmu należy podkreślić, że w swoim osądzie problemu opierał się przede wszystkim na zdaniu Jana Kasjana oraz Cyryla Aleksandryjskiego. Ponadto w realizacji swej decyzji posłużył się pośrednictwem patriarchy Aleksandrii, który z natury był człowiekiem porywczym i nieskłonnym do budowania pokoju. Potwierdzi to przebieg obrad soboru w Efezie w 431 r. Celestyn został zaproszony na sobór. Nie uczestniczył w nim jednak osobiście, a jedynie wysłał trzech legatów, którym nakazał ścisłą współpracę z patriarchą Aleksandrii. Wysłannicy Celestyna spóźnili się niestety do Efezu. Kiedy tam przybyli w dniu 10 lipca, przyszło im tylko zatwierdzić decyzje podjęte przez sobór zgromadzony w dniu 22 czerwca $431 \mathrm{r}$. pod przewodnictwem Cyryla9. Celestyn podjęte uchwały, mimo sprzeciwu patriarchy Antiochii Jana, przyją z zadowoleniem, co wyraził listownie w $432 \mathrm{r}$. Wszystkie działania Celestyna wskazuja na jego świadomość odpowiedzialności za Kościół. Wielokroć podkreślał, że jako następca św. Piotra ma szczególne prawo do sprawowanie pieczy nad całym Kościołem. Trzeba przyznać, że swoimi działaniami przyczynił się do zachowania prawowierności nie tylko w kwestii nestorianizmu. Jego zasługa jest również zakończenie schizmy nowacjan, zajmował też jednoznaczne stanowisko wobec pelagianizmu i semipelagianizmu. Warto tu wspomnieć, że takie stanowisko Celestyna, spotykało się jednak ze zdecydowanym oporem niektórych wspólnot kościelnych, spośród których należy wymienić Kościół północnoafrykański ${ }^{10}$.

2. Papież Leon Wielki wobec nauczania Eutychesa. Wsparcia w Rzymie szukał również Eutyches, archimandryta konstantynopolitański. Głoszona przez niego chrystologia została potępiona na synodzie w Konstantynopolu w 448 r., a on sam ekskomunikowany. Należy podkreślić, że synod wielokrotnie wzywał Eutychesa do stawienie się przed uczestników obrad w celu wyjaśnienia swoich poglądów ${ }^{11}$. Kiedy wreszcie dotarł, jego nauczanie zostało

\footnotetext{
${ }^{7}$ Por. Caelestinus, Epistula XIII ad Nestorium 18, ŹMT 52 [tekst grecko-łacińsko-polski, układ i oprac. A. Baron - H. Pietras, tłum. S. Kaczmarek], Kraków 2010 = SCL 4, 332-332*.

${ }^{8}$ Por. tenże, Epistula XIV ad clerum et populum Constantinopoltanum 21-23, SCL 4, 346-347*.

${ }^{9}$ Por. Starowieyski, Sobory niepodzielonego Kościoła, s. 79-81.

${ }^{10}$ Por. J.N.D. Kelly, Encyklopedia papieży, tłum. T. Szafrański, Warszawa 2007, 63-64.

${ }^{11}$ Por. Concilium Constantinopolitanum (448), Gesta Constantinopolis 488-551, ŹMT 62 [tekst
} 
uznane za nieprawowierne, a on sam ekskomunikowany i pozbawiony wszelkich urzędów:

„Dlatego pośród łez i jęków nad jego [tj. Eutychesa] całkowitą zgubą postanowiliśmy, przez Pana naszego Jezusa Chrystusa, któremu on bluźnił, że zostaje on pozbawiony wszelkiej pozycji kapłańskiej, komunii z nami oraz przewodniczenia klasztorowi, ponieważ wszyscy wiedza, że od tego momentu rozmawiając z nim oraz stykając się z nim, staną się sami narażeni na karę ekskomuniki, skoro nie unikali przebywania z nim"'2.

Wyrok ten podpisali m.in. Flawian, biskup Konstantynopola, Bazyli, biskup Seleucji, Eulalios, biskup Chalcedonu, w sumie 53 uczestników synodu. W tej sytuacji Eutyches skierował list do ówczesnego biskupa Rzymu, Leona ( $\uparrow$ 461). Pismo trafiło do adresata w lutym 449 r. Eutyches nazywa w swoim liście Leona obrońca prawowierności - warto to podkreślić. Wyjaśniając biskupowi Rzymu swoje poglądy, potępiał zdecydowanie nauczanie Nestoriusza, Apolinarego oraz twórców innych herezji. W ten sposób starał się udowodnić przywiązanie do prawowiernej nauki Kościoła, co miało z pewnością pomóc $\mathrm{w}$ uzyskaniu poparcia ze strony Leona ${ }^{13}$. Jednak, jak wskażą na to późniejsze wydarzenia, pisząc list do papieża, Eutyches nie był gotów podporządkować się jego decyzji w sprawie głoszonej przez siebie nauki. Eutyches napisał jednocześnie jeszcze kilka listów, w których prosił o poparcie nie tylko Leona, ale także cesarza Teodozjusza II, Dioskura, patriarchy Aleksandrii oraz Piotra Chryzologa, biskupa Rawenny ${ }^{14}$.

Argumenty przedstawione przez Eutychesa nie przekonały Leona. Uznał list archimandryty za mało precyzyjny w swojej treści. Nie może więc dziwić fakt, że pisząc do Flawiana swój słynny list dogmatyczny, określi Eutychesa jako nieroztropnego, słabo wykształconego, a jednocześnie pysznego. Wskazuje na to jego postawa, gdyż - zdaniem Leona - Eutyches nie szukał odpowiedzi na rodzące się w nim pytania dotyczące osoby Chrystusa w Piśmie Świętym, ale we własnych przemyśleniach. Papież pisał:

„Eutyches, który wydawał się godny czci jako prezbiter, okazał się wielce nieroztropny i za mało wykształcony. Można zastosować do niego słowa Proroka: «Nie chciał zrozumieć, aby dobrze czynić; nieprawość obmyślał na łożu swoim» (Ps 35, 4)"’15.

grecko-polski, układ i oprac. A. Baron - H. Pietras, tłum. S. Kaczmarek], Kraków $2011=$ SCL 6, 99-102*.

${ }^{12}$ Por. tamże 551, SCL 6, 102-102*.

${ }^{13}$ Por. Eutyches, Epistula 21 [ad S. Leonem], 3, PL 54, 717-718.

${ }^{14}$ Por. W.A. Jurgens, The Faith of the Early Fathers: St. Augustine to the End of the Patristic Age, Collegeville 1979, 267.

${ }^{15}$ Leo Papa, Epistula ad Flavianum, ep. Constantinopolitanum de Eutyche 1, ŹMT 24 [tekst łacińsko-polski, układ i oprac. A. Baron - H. Pietras, tłum. T. Wnętrzak], Kraków $2001=$ DSP 1 , 196-197. 
Swoją wiedzę na temat poglądów Eutychesa, Leon czerpał nie tylko z jego listu. Miał bowiem do dyspozycji bardzo szczegółowo opisujący herezję list od patriarchy Konstantynopola Flawiana. Jako dobry teolog, Leon zredagował swoje słynne pismo, znane jako List Dogmatyczny do Flawiana (Tomus ad Flavianum), w którym zawarł prawowierne nauczanie na temat natur w Chrystusie, przeciwstawiając się jednoznacznie poglądom głoszonym przez Eutychesa. Warto podkreślić, że papież dokonał dogłębnej systematyzacji idei głoszonych przez swoich poprzedników, sięgając do dorobku całej Tradycji starożytnego Kościoła ${ }^{16}$. Na synod generalny zwołany w sprawie nauczania Eutychesa przez Teodozjusza II do Efezu w 449 r. biskup Rzymu wysłał swoich trzech legatów. Przebieg tego zgromadzenia określanego przez Leona jako Latrocinium Ephesianum jest powszechnie znany ${ }^{17}$. Prawowierni biskupi, wśród nich patriarcha Konstantynopola - Flawian zostali potępieni, nie odczytano Tomu Leona, a Eutyches został zrehabilitowany. Informację o przebiegu soboru, na którym dopuszczono się nawet użycia siły, przyniósł do Rzymu jeden z legatów, diakon Hilary, który zdołał uciec z miejsca ob$\operatorname{rad}^{18}$. W tej trudnej sytuacji Leon bez żadnych wątpliwości zanegował uchwały podjęte na synodzie efeskim i, nie załamując rąk, zaczął zabiegać o rewizję powziętych postanowień. Papież działał bardzo szybko i zdecydowanie. Już w dniu 29 września 449 r. zwołał w Rzymie synod, na którym został potępiony „sobór zbójecki”. Wraz z uczestnikami synodu wysłał listy do cesarza Teodozjusza ${ }^{19}$, do jego siostry cesarzowej Pulcherii ${ }^{20}$ oraz do kleru i mnichów Konstantynopola ${ }^{21}$, tworząc w ten sposób szeroką opozycję wobec postanowień efeskich. Sprzeciw wobec uchwał w Efezie wyrazili także biskupi Galii i Italii. Na prośbę Leona pośrednictwa w dyskusji z cesarzem Teodozjuszem II podjął się Walentynian III. Jednak cesarz Wschodu pozostał w swojej postawie nieugięty. Sytuacja zmieniła się dopiero po nagłej śmierci Teodozjusza II (450), który nie pozostawił po sobie męskiego potomka. Władzę objęła wówczas Pulcheria, siostra Teodozjusza, ogłoszona augustą jeszcze w dzieciństwie. Po zawarciu związku małżeńskiego z Marcjanem, oboje, jako zwolennicy prawowiernej nauki, starali się porozumieć z Leonem w sprawie zakończenia toczących się dyskusji. Mimo wątpliwości biskupa Rzymu, co do potrzeby zwołania w tej sprawie kolejnego soboru powszechnego, ostatecznie

${ }^{16}$ Por. J.N.D. Kelly, Poczatki doktryny chrześcijańskiej, tłum. J. Mrukówna, Warszawa 1988, 250-251.

${ }^{17}$ Por. S. Wessel, Leo the Great and the Spiritual Rebuilding of a Universal Rome, Leiden 2008, 259-261.

${ }^{18}$ Por. Leo Papa, Epistula 42 [ad Pulcheriam Augustam] 3, PL 84, 705.

${ }^{19}$ Por. Concilium Romanum (449), Epistula Leonis et synodi ad Theodosium (13 octobris 449), SCL 6, 172-174*.

${ }^{20}$ Por. Concilium Romanum (449), Epistula Leonis et synodi ad Pulcheriam (13 octobris 449), SCL 6, 174-176*.

${ }^{21}$ Por. Concilium Romanum (449), Epistula Leonis et synodi ad clero et plebi Constantinopoli, SCL 6, 176-177*. 
po wymianie listów ustalono, że sobór zbierze się w dniu 1 września $451 \mathrm{r}$. w Nicei ${ }^{22}$. Ponieważ jednak cesarz nie mógł przybyć do Nicei, sobór został przeniesionych do Chalcedonu, do kościoła św. Eufemii. Leona reprezentowało trzech legatów, jego przedstawiciel w Konstantynopolu oraz notariusz. Warto podkreślić, że papież kategorycznie zażądał, aby to jego legaci przewodniczyli obradom soboru. Same obrady miały miejscami dramatyczny przebieg. Legaci papiescy przyjęli bardzo twarde stanowisko o konieczności włączenia do tekstu uchwał soborowych formuł z Tomu do Flawiana. Nie zgodzili się również na przyjęty podczas ich nieobecności na sali kanon 28., w którym uchwalono, że Konstantynopol jako miasto cesarskie, ma te same przywileje co Rzym. Uczestnicy soboru na końcu obrad zredagowali list do Leona, w którym prosili go o zatwierdzenie powziętych w czasie obrad postanowieńn ${ }^{23}$. Papież w 453 r. przyjął jednak tylko te uchwały, które dotyczyły prawd wiary (in sola fidei causa) ${ }^{24}$.

Podsumowując, należy podkreślić zaangażowanie i determinację Leona w rozwiązanie problemu monofizytyzmu, a jednocześnie precyzję języka teologicznego, tak ważną w formułowaniu opisu prawd wiary. $Z$ drugiej jednak strony trzeba wspomnieć o postawie Eutychesa, który nie przyjął nauczania soborowego. Sobór choć wyraźnie określił ramy prawowierności nie zakończył się jednak pełnym sukcesem, nie doprowadził bowiem do jedności w chrześcijaństwie. Część wspólnot, przede wszystkim w Syrii i Egipcie pozostała bowiem wierna nauczaniu Eutychesa ${ }^{25}$.

3. Postawa biskupów Rzymu wobec wyznawców monoteletyzmu. Problem monoteletyzmu pojawił się w VII w. i miał podłoże polityczne. Wobec szerzącego się islamu, a przede wszystkim wskutek zajęcia Egiptu i Syrii przez Persów, cesarzowi Herakliuszowi zależało na pojednaniu z monofizytami. Zamieszkiwali oni tereny podbite przez Persów. Pozyskanie ich do jedności wiary, ułatwiłoby cesarzowi odbicie Egiptu i Syrii, i ponowne włączenie tych terenów do Imperium ${ }^{26}$. Taka możliwość pojawiła się w związku z poglądami głoszonymi przez patriarchę Konstantynopola Sergiusza I. Uznawał on dwie natury w Chrystusie, ale jedną Bosko-ludzką energię i jedno działanie woli Chrystusa. Zdaniem Sergiusza działanie bowiem wynika z osoby,

${ }^{22}$ Por. E. Wipszycka, Kościót w świecie późnego antyku, Warszawa 1994, 233.

${ }^{23}$ Por. Concilium Chalcedonense (451), Epistula 98 [ad Sanctissimum Papam Romanae Ecclesiae Leonem], PL 54, 951-960; Hefele - Leclercq II/2 835-838.

${ }^{24}$ Por. Leo Papa, Epistula 114 [ad episcopos, qui in sancta synodo chalcedonensi congregati fuerunt, directa], PL 54, 1027-1032; Hefele - Leclercq, Histoire des conciles, II/2 839-844; A. Olmi, Il consenso cristologico tra la chiese calcedonesi e non calcedonesi (1964-1996), Roma 2003, 100-101.

${ }^{25}$ Por. P. Siniscalco, Starożytne Kościoły Wschodnie. Historia i literatura, thum. K. Piekarz, Kraków 2013, 159-161.

${ }^{26}$ Por. B. Flusin, Tryumf chrześcijaństwa i określenie prawowierności, w: Świat Bizancjum, t. 1, s. 93. 
a nie z natury ${ }^{27}$. Niebezpieczeństwo takiej chrystologii dostrzegł mnich jerozolimski Sofroniusz. Jego rola w tym sporze wzrośnie z chwilą wybrania go na biskupa Jerozolimy. O swoim wyborze powiadomił innych patriarchów, a wśród nich Sergiusza oraz Honoriusza ( $†$ 638), biskupa Rzymu. W skierowanych do nich listach oprócz informacji o wyborze na stolicę w Jerozolimie, przedstawił i jednocześnie potępił wszelkie ówczesne herezje, wiele miejsca poświęcając wyjaśnieniu błędu monoteletyzmu ${ }^{28}$. W międzyczasie do Honoriusza zwrócił się również Sergiusz. Chociaż uwagę zwraca fakt oczekiwania patriarchy Konstantynopola na poparcie przez biskupa Rzymu, to jednak nie należy tu doszukiwać się zmiany stanowiska Sergiusza na temat roli, jaką pełni w Kościele biskup Rzymu. Sergiusz nie szukał u papieża porady, ale tylko i wyłączenie poparcia dla głoszonych przez siebie tez. Ponadto miał w liście do papieża dopuścić się fałszowania dokumentów tradycji ${ }^{29}$. Prosił więc Honoriusza o wydanie zakazu prowadzenia jakichkolwiek dyskusji na temat jednego czy dwóch sposobów działania w Chrystusie. Biskup Rzymu przyjął propozycję Sergiusza. W sformułowanej pośpiesznie, bez podjęcia głębszej refleksji, odpowiedzi adresowanej do patriarchy Konstantynopola, wspomniał o jednej woli Chrystusa: ,,przyjmujemy jedną wolę Pana naszego Jezusa Chrystusa" $^{30}$. Zdanie to dla swoich celów Sergiusz skrzętnie wykorzystał. Owoc swoich refleksji teologicznych Honoriusz przesłał nie tylko do Sergiusza, lecz także do innych adresatów, również do Sofroniusza. W tej sytuacji, mając poparcie biskupa Rzymu, cesarz w 638 r., już po śmierci Honoriusza, ogłosił przygotowane przez Sergiusza pismo Ekthesis - Wyjaśnienie wiary, w którym zabronił wszelkich dyskusji na temat jednego lub dwu działań w Chrystusie, a nakazał wyznawanie w Nim jednej woli ${ }^{31}$.

W walce $\mathrm{z}$ monoteletyzmem, a tym samym w działaniach na rzecz przywrócenia ortodoksyjnej nauki, ważną rolę odegrało wielu kolejnych biskupów Rzymu. Należy wspomnieć tu Jana IV († 642), który w 641 r. zwołał w Rzymie synod, którego uczestnicy uznali jednogłośnie monoteletyzm za herezję $e^{32}$. Papież umocniony decyzjami synodalnymi bronił ortodoksji. Było to o tyle trudne, że kolejny patriarcha Konstantynopola Pyrrus I przywoływał opinię wyrażoną przez poprzednika Jana IV, Honoriusza I. W tej sytuacji papież, broniąc prawowiernego nauczania, starał się jednocześnie usprawiedliwić stanowisko swego poprzednika twierdząc, że mówiąc o jednej woli Chrystusa, Honoriusz miał na myśli Jego ludzką wolę. Dowodził dalej, że wola Chrystusa

\footnotetext{
${ }^{27}$ Por. G.L. Müller, Dogmatyka katolicka, tłum. W. Szymona, Kraków 2015, 285; Starowieyski, Sobory niepodzielonego Kościoła, s. 128.

${ }^{28}$ Por. O. Kashchuk, Aktywność cesarza w kontekście sporów chrystologicznych w Bizancjum w VII wieku, VoxP 36 (2016) t. 66, 413.

${ }^{29}$ Por. S. Głowa - I. Bieda, BF 238.

${ }^{30}$ Honorius I Papa, Epistula 4 [ad Sergium Constantinopolitanum episcopum], PL 80, 472, tłum. Głowa - Bieda, BF 239.

${ }^{31}$ Por. Kelly, Encyklopedia papieży, s. 103.

${ }^{32}$ Por. Concilium Romanum (640), Mansi X 697-700.
} 
była wolna od podziałów, inaczej niż ma to miejsce w przypadku wszystkich ludzi skażonych grzechem pierworodnym ${ }^{33}$. W swoich działaniach przeciwko zwolennikom monoteletyzmu, Jan IV domagał się od cesarza Konstantyna III usunięcia z miejsc publicznych Konstantynopola wszystkich egzemplarzy Ekthesis uznającego monoteletyzm za oficjalne nauczanie Kościoła ${ }^{34}$.

Następca Jana VI na stolicy piotrowej, Teodor I († 649), zaraz po objęciu urzędu podjął działania na rzecz potępienia monoteletyzmu. W tym celu skierował list do cesarza Konstansa II i patriarchy Konstantynopola Pawła II w sprawie obowiązującego wciąż Ekthesis ${ }^{35}$. Ostatecznie cesarz, widząc brak efektów obowiązywania Ekthesis w nawiązaniu jedności z monofizytami, a jednocześnie uznając szkody, jakie wnosiło ono w relacjach z Zachodem, odwołał je w 648 r. Równocześnie ogłosił jednak przygotowany przez patriarchę Pawła II edykt (tzw. Typos), w którym odwołując Ekthesis nakazał ograniczenie nauki Kościoła do orzeczeń przyjętych przez pięć pierwszych soborów $^{36}$. W tym samym piśmie zakazywał dyskusji na temat liczby woli i działań w Chrystusie. Wydanie Typos nie oznaczało żadnej zmiany w poglądach Konstansa II, o czym świadczy jego postawa wobec następcy Teodora, papieża Marcina I $(\dagger 655)^{37}$. Warto w tym miejscu wspomnieć opinię Johna Normana Davidsona Kelly'ego, który jest przekonany, że Teodor I z całą pewnością potępiłby Typos, gdyby wcześnie nie umarł ${ }^{38}$.

Marcin I podjął także działania na rzecz przywrócenia ortodoksji. W tym celu zwołał w 649 r. synod na Lateranie, w czasie którego zebrani biskupi i mnisi przestudiowali zarówno pisma Ojców Kościoła, jak i tezy zwolenników monoteletyzmu ${ }^{39}$. Ostatecznie uczestnicy synodu wypowiedzieli się kategorycznie przeciwko nauce o jednej woli i jednym działaniu w Chrystusie:

„Jeśli ktoś według nauki bezbożnych heretyków przyjmuje jedną wolę i jedno działanie w myśl heretyckiego wyznania, a przeczy i odrzuca dwie wole i dwa działania, to jest Boskie i ludzkie, które w Chrystusie Bogu zachowują harmonię i co prawowiernie głoszą o Nim święci Ojcowie - niech będzie wyklęty"40.

Ojcowie synodu w opracowanych kanonach, potępiających monoteletyzm, przyjęli argument z Tradycji. Jednocześnie użyli formuły negatywnej

\footnotetext{
${ }^{33}$ Por. Joannes IV Papa, Epistula 2 [ad Constantinum Imperatorem], PL 80, 603-604.

${ }^{34}$ Por. Kelly, Encyklopedia papieży, s. 105; P. Booth, Crisis of Empire: Doctrine and Dissent at the End of Late Antiquity, Berkeley 2014, 282.

${ }^{35}$ Por. Theodorus I Papa, Epistula ad Paulum Patriarcham Constantinopolitanum, PL 87, 75 80; Kashchuk, Aktywność cesarza w kontekście sporów chrystologicznych, s. 414-415.

${ }^{36}$ Por. Hefele - Leclercq, III 432-434.

${ }^{37}$ Por. P. Szczur, Marcin I, EK XI 1237.

${ }^{38}$ Por. Kelly, Encyklopedia papieży, s. 106-107.

${ }^{39}$ Por. H. Chadwick, Historia rozłamu Kościoła Wschodniego i Zachodniego: od czasów apostolskich do Soboru Florenckiego, tłum. P. Sajdek, Kraków 2009, 88.

${ }^{40}$ Concilium Lateranense (649), can. 14, ed. R. Riedinger: Concilium Lateranense a. 649 celebratum, ACO II/1, Berlin 1984, 377, thum. Głowa - Bieda, BF 242.
} 
W redakcji treści kanonów kończąc je anatematyzmem. Tak więc wszyscy twórcy i wyznawcy monoteletyzmu, wraz z nieżyjącym już Sergiuszem, zostali potępieni i ekskomunikowani. Ich imiona zostały wymienione w kanonach 18-20. W kanonach tych potępiono również, co należy uznać jako wielki akt odwagi ojców synodalnych, dokumenty cesarskie Ekthesis i Typos ${ }^{41}$. Marcin o przyjętych uchwałach synodalnych poinformował zarówno cesarza ${ }^{42}$, jak i licznych biskupów. Za swoją wierność ortodoksji papież wiele wycierpiał od cesarza Konstansa II, zagorzałego zwolennika monoteletyzmu. Cesarz po porwaniu już ciężko chorego papieża z Rzymu (653), wytoczył mu w Konstantynopolu pokazowy proces, w czasie którego, na podstawie fałszywych zeznań podstawionych świadków, został skazany na śmierć. Ostatecznie jednak, na prośbę umierającego patriarchy Pawła II, karę śmierci zamieniono na wygnanie na Krym. Wycieńczony Marcin I zmarł w Chersonezie na Krymie w dniu 16 września $655 \mathrm{r}$. w glorii męczennika ${ }^{43}$.

Na problem trwającej w Kościele schizmy nie pozostali obojętni kolejni biskupi Rzymu. Starali się oni przywrócić jedność Kościoła. Adeodat II († 676) nie przyjął wyznania wiary patriarchy Konstantynopola, Konstantyna I, zwolennika monoteletyzmu ${ }^{44}$. Także Donus († 678) musiał zmierzyć się z problemem podziału Kościoła. Mimo, że kolejny patriarcha Konstantynopola Teodor I był zwolennikiem monoteletyzmu, to jednak działania pojednawcze podjął cesarz Konstantyn IV. Wystosował on list do papieża, który dotarł do Rzymu już po śmierci Donata ${ }^{45}$. Dzieło pojednania podjął zatem jego następca, Agaton († 681). Cesarzowi zależało na zażegnaniu trwającej od chwili potępienia Sergiusza schizmy trwającej już 30 lat. W swoim liście Konstantyn IV zaproponował, aby do Konstantynopola przybyli odpowiednio przygotowani przedstawiciele Rzymu i w dyskusji z teologami Wschodu doszli do tak oczekiwanego porozumienia. Aby wypełnić prośbę cesarza, Agaton podjął wszelkie niezbędne działania, mające na celu jak najlepsze przygotowanie się do dyskusji z teologami Wschodu. W tym celu zostały zwołane synody m.in. w Heatfield, w Mediolanie, w Rzymie, na których wypracowano wspólne stanowisko episkopatu Kościoła Zachodniego potępiające monoteletyzm ${ }^{46}$. Wybrana delegacja zawiozła do Konstantynopola list Agatona adresowany do cesarza oraz dekret synodu rzymskiego. W dokumentach tych przekazano treść przyjętych na synodzie uchwał, a także podkreślono znaczenie stolicy rzymskiej, która jest prawdziwym strażnikiem prawowierności ${ }^{47}$. Zebrany w Konstantynopolu sobór trwający od 7 listopada $680 \mathrm{r}$. do 16 września 681 r. potwierdził w pełni

\footnotetext{
${ }^{41}$ Por. Hefele - Leclercq, III 448-449.

${ }^{42}$ Por. Martinus I Papa, Epistula 3 [ad Constantem Imperatorem], PL 87, 137-146.

${ }^{43}$ Por. Hefele - Leclercq, III 459-460; Kelly, Encyklopedia papieży, s. 108.

${ }^{44}$ Por. Kelly, Encyklopedia papieży, s. 111.

${ }^{45}$ Por. Flavius Constantinus Imp., Epistula ad Donum Papam, PL 87, 1147-1154.

${ }^{46}$ Por. Hefele - Leclercq, III 475-476.

${ }^{47}$ Por. Concilium Romanum (680), Mansi XI 185-188; Hefele - Leclercq, III 481.
} 
papieskie nauczanie o dwóch wolach i dwóch działaniach w Chrystusie. Zebrani ojcowie synodalni uznali także ogromny wkład Agatona, który niestety w międzyczasie zmarł (681), w zachowanie prawdziwej wiary.
„Obecny święty i powszechny sobór wita z wyciągniętymi rękami i z wiarą przyjmuje listowną relację Agatona, najświętszego i błogosławionego papie- ża starożytnego Rzymu"48.

Jednocześnie sobór, wśród twórców i głosicieli monoteletyzmu, potępił także Honoriusza $\mathrm{I}^{49}$. Warto zauważyć, że decyzja piętnująca działania Honoriusza została przyjęta przez uczestników soboru, także ze strony legatów papieskich. Henry Chadwick uważa, że była to cena, jaką biskupi greccy zgodzili się zapłacić za przyjęcie uchwał soborowych. Ostatecznie imię Honoriusza I umieszczono na liście potępionych przez sobór zwolenników monoteletyzmu pomiędzy imionami patriarchów Konstantynopola ${ }^{50}$.

Uchwały soborowe potwierdził Leon II, biskup Rzymu w latach 682-683. W liście skierowanym do cesarza Konstantyna odniósł się również do potępienia przez VI sobór powszechny swego poprzednika Honoriusza I i broniąc go wyjaśnił, że „,pozwolił na wypaczenie nieskalanej wiary” i należy go piętnować nie za herezję, lecz „za niedbałość w sprawowaniu swoich obowiązków”51.

\section{$* * *$}

Stolica Apostolska cieszyła się w starożytności chrześcijańskiej autorytetem obrońcy prawowierności. Z tego powodu poparcia ze strony biskupów Rzymu szukali również twórcy błędnych nauk. Z reguły jednak, jak wykazała to praktyka, nie byli oni gotowi do przyjęcia posłuszeństwa papieżowi i odwołania głoszonych przez siebie tez, w przypadku, gdy biskup Rzymu uznawał ich nieprawowierność.

Należy podkreślić ogromną aktywność biskupów Rzymu w obronie prawowierności. Poprzez liczne działania, takie jak synody czy szeroką korespondencję, zabiegali o przedstawienie prawowiernego nauczania i potępienie herezji. Niektórzy z nich, jako dobrzy teologowie (Leon Wielki, Agaton), osobiście opracowywali i przedstawiali ortodoksyjną wykładnię dyskutowanych prawd wiary, inni (Celestyn) świadomi braku odpowiedniej wiedzy, korzystali z pomocy znawców tematu (Jan Kasjan, Cyryl Aleksandryjski). Wszyscy mieli wysokie poczucie odpowiedzialności za cały Kościół i zachowanie w nim prawowiernego nauczania. Swoją wierność ortodoksji przepłacali niekiedy osobistym

\footnotetext{
${ }^{48}$ Concilium Constantinopolitanum III (680-681), Expositio fidei 11 [tekst grecko-łacińsko-polski, tłum. A. Baron], DSP 1, 315.

${ }^{49}$ Por. tamże 8.

${ }^{50}$ Por. Chadwick, Historia rozłamu Kościoła Wschodniego i Zachodniego, s. 92.

${ }^{51}$ Leo II Papa, Epistula 3 [ad Constantinum Imperatorem], PL 96, 409, tłum. Głowa - Bieda, BF 247.
} 
cierpieniem, a nawet śmiercią (Marcin I). Jedynym biskupem Rzymu, którego postawa budziła poważne wątpliwości był Honoriusz I. Forma, poparcie tez monoteletyzmu oraz motywacja, były przedmiotem wielu dyskusji i ocen.

\section{THE ROLE OF THE BISHOPS OF ROME IN THE DOCTRINAL DISPUTES OF THE ANCIENT CHURCH}

(Summary)

This article presents the role of the bishops of Rome in the resolution of three doctrinal disputes (nestorianism, monophysitism, monothelitism) that hit the community of the Church between the $5^{\text {th }}$ and the $7^{\text {th }}$ centuries. Both the teaching of Nestorius and Eutyches were unequivocally condemned by the contemporary bishops of Rome, respectively Celestine and Leon the Great. Their teachings were confirmed by the general councils of Ephesus (431) and Chalcedon (451). Solving the problem of monothelitism has caused even more difficulties to the Holy See because of the attitude of Honorius I, who supported the erroneous teaching of the Patriarch of Constantinople, Sergei. Thus, the work discusses the actions of the subsequent bishops of Rome (especially John IV, Theodore, Martin I and Agathon) for restoring orthodoxy, which resulted in the adoption of resolutions condemning monothelitism by the Third Council of Constantinople (680-681). The article was primarily written on the basis of the preserved correspondence between heresiarchs and the bishops of Rome, the bishops of Rome and the emperors, as well as the resolutions of synods and councils.

Key words: Holy See, nestorianism, monophysitism, monothelitism, Celestine I, Leo the Great, Honorius I, Agathon.

Słowa klucze: Stolica Apostolska, nestorianizm, monofizytyzm, monoteletyzm, Celestyn I, Leon Wielki, Honoriusz I, Agaton.

\section{BIBLIOGRAFIA}

\section{Źródła}

Caelestinus, Epistula XIII ad Nestorium, tekst grecko-łacińsko-polski, układ i oprac. A. Baron-H. Pietras, thum. S. Kaczmarek, ŹMT 52 = SCL 4, Kraków 2010, 320-333*.

CAelestinus, Epistula XIV ad clerum et populum Constantinopoltanum, tekst grecko-łacińsko-polski, układ i oprac. A. Baron - H. Pietras, tłum. S. Kaczmarek, ŹMT 52 $=$ SCL 4, Kraków 2010, 333-347*.

Codex Theodosianus XVI, tekst łacińsko-polski, oprac. M. Ożóg - M. Wójcik, wstęp M. Stachura, thum. A. Caba, ŹMT 71 = SCL 7, Kraków 2014.

Concilium Chalcedonense (451), Epistula 98 [ad Sanctissimum Papam Romanae Ecclesiae Leonem], PL 54, 951-960, PL 54, 951-960. 
Concilium Constantinopolitanum (448), Gesta Constantinopolis, tekst grecko-polski, układ i oprac. A. Baron - H. Pietras, tłum. S. Kaczmarek, ŹMT 62 = SCL 6, Kraków 2011, 62-105*.

Concilium Constantinopolitanum III (680-681), Expositio fidei, tekst grecko-łacińsko-polski, układ i oprac. A. Baron - H. Pietras, tłum. A. Baron, ŹMT 24 = DSP 1, Kraków 2001, 308-323.

Concilium Lateranense a. 649 celebratum, ed. R. Riedinger, ACO II/1, Berlin 1984.

Concilium Romanum (449), Epistula Leonis et synodi ad clero et plebi Constantinopoli, tekst łacińsko-polski, układ i oprac. A. Baron - H. Pietras, tłum. B. Tobor, ŹMT 62 = SCL 6, Kraków 2011, 176-177*.

Concilium Romanum (449), Epistula Leonis et synodi ad Pulcheriam (13 octobris 449), tekst łacińsko-polski, układ i oprac. A. Baron - H. Pietras, tłum. B. Tobor, ŹMT 62 = SCL 6, Kraków 2011, 174-176*.

Concilium Romanum (449), Epistula Leonis et synodi ad Theodosium (13 octobris 449), tekst łacińsko-polski, układ i oprac. A. Baron - H. Pietras, tłum. B. Tobor, ŹMT 62 = SCL 6, Kraków 2011, 172-174*.

Eutyches, Epistula 21 [ad S. Leonem], PL 54, 713-720.

Flavius Constantinus ImP., Epistula ad Donum Papam, PL 87, 1147-1154.

Honorius I PAPA, Epistula 4 [ad Sergium Constantinopolitanum episcopum], PL 80, 470-474.

JoAnNes IV PAPA, Epistula 2 [ad Constantinum Imperatorem], PL 80, 602-608.

LEO II PAPA, Epistula 3 [ad Constantinum Imperatorem], PL 96, 399-412.

LEO PAPA, Epistula 114 [ad episcopos, qui in sancta synodo chalcedonensi congregati fuerunt, directa], PL 54, 1027-1032.

Leo PAPA, Epistula 42 [ad Pulcheriam Augustam], PL 84, 705-706.

Leo PAPA, Epistula ad Flavianum, ep. Constantinopolitanum de Eutyche, tekst łacińsko-polski, układ i oprac. A. Baron - H. Pietras, tłum. T. Wnętrzak, ŹMT $24=$ DSP 1 , Kraków 2001, 196-213.

Martinus I PAPA, Epistula 3 [ad Constantem Imperatorem], PL 87, 137-146.

Nestorius, Epistula 6 [ad Coelestinum Papam Urbis Romae], PL 50, 438-441.

Theodorus I PAPA, Epistula ad Paulum Patriarcham Constantinopolitanum, PL 87, 75-80.

Opracowania

Bоотн P., Crisis of Empire: Doctrine and Dissent at the End of Late Antiquity, Berkeley 2014.

Ceran W., Teodozjusz Wielki, Kraków 2003.

CHADwick H., Historia rozłamu Kościoła Wschodniego i Zachodniego: od czasów apostolskich do Soboru Florenckiego, tłum. P. Sajdek, Kraków 2009.

Hefele Ch. - Leclerce H., Histoire des conciles d'après les documents originaux, II/2, Paris 1908.

Hefele Ch. - LeClercQ H., Histoire des conciles d'après les documents originaux, III, Paris 1909.

Jurgens W.A., The Faith of the Early Fathers: St. Augustine to the End of the Patristic Age, Collegeville 1979.

Karas M., Życie Nestoriusza, patriarchy Konstantynopola ( $V$ w.), „Nowy Filomata” 4 (2001) 262-271.

Kashchuk O., Aktywność cesarza w kontekście sporów chrystologicznych w Bizancjum w VII wieku, VoxP 36 (2016) t. 66, 411-428.

Kelly J.N.D., Encyklopedia papieży, tłum. T. Szafrański, Warszawa 2007. 
Kelly J.N.D., Poczatki doktryny chrześcijańskiej, tłum. J. Mrukówna, Warszawa 1988.

Müller G.L., Dogmatyka katolicka, thum. W. Szymona, Kraków 2015.

OLmi A., Il consenso cristologico tra la chiese calcedonesi e non calcedonesi (1964-1996), Roma 2003.

SesboüÉ B., Chrystologia i soteriologia. Efez i Chalcedon (IV-V wiek), w: Historia dogmatów, t. 1: Bóg zbawienia, red B. Sesboüé, thum. P. Rak, Kraków 1999, 301-441.

Siniscalco P., Starożytne Kościoły Wschodnie. Historia i literatura, thum. K. Piekarz, Kraków 2013.

Słownik Wczesnochrześcijańskiego Piśmiennictwa, red. M. Starowieyski - J.M. Szymusiak, Poznań 1971.

Starowieyski M., Sobory niepodzielonego Kościoła, Kraków 2016.

Szczur P., Marcin I, EK XI 1237.

Świat Bizancjum, t. 1: Cesarstwo wschodniorzymskie 330-641, red. C. Morrisson, tłum. A. Graboń, Kraków 2007.

Wessel S., Leo the Great and the Spiritual Rebuilding of a Universal Rome, Leiden 2008.

WIPSZYCKA E., Kościół w świecie późnego antyku, Warszawa 1994. 
